Journal of Social Sciences 6 (1): 60-63, 2010

ISSN 1549-3652

(C) 2010 Science Publications

\title{
Effects of Learning Environmental Education on Science Process Skills and Critical Thinking of Mathayomsuksa 3 Students with Different Learning Achievements
}

\author{
${ }^{1}$ Phramaha Charoen Buntod, ${ }^{1}$ Paitun Suksringam and ${ }^{2}$ Adisak Singseevo \\ ${ }^{1}$ Faculty of Environment and Resource Studies, \\ University of Mahasarakham, Mahasarakham, 44150, Thailand \\ ${ }^{2}$ Faculty of Education, University of Mahasarakham 44150, Thailand
}

\begin{abstract}
Problem statement: The object of this research aimed to investigate and compare effects of learning environmental education by wises of two approaches: The 5 E-Learning cycle with met cognitive techniques and the teacher's handbooks, on learning achievement, basic science process skills and critical thinking of 75 Mathayomsuksa 3 (grade 9) students with different learning achievements. Approach: They were assigned to an experimental group with 38 students who learned using the 5 E-Learning cycle with met cognitive techniques and a control group with 37 students who learned using the teacher's handbook approach. Instruments used in the study included (1) 6 plans of learning organization using the 5 E-Learning cycle with 3 met cognitive techniques: Intelligibility, plausibility and wide applicability, 6 plans of learning organization using the teacher's handbook, approach; each plan for $3 \mathrm{~h}$ of learning in each week; (2) the learning achievement test with 40 item; (3) the test on basic science process skills with 8 subclass and 40 items and (4) the critical thinking test with 5 subclass and 54 items. The data were analyzed by the uses of a percentage, mean, a standard deviation, the paired t-test and the f-test (two-way MANCOVA). Results: The whole students, The high achievers and the low achievers in the experimental group showed gains in learning achievement, basic science process skills in general and in 3-6 subclass and critical thinking in general and in 4-5 subclass from before learning at the 0.05 level of significance. The experimental group indicated more learning achievement, basic science process skills in general and in 2 subclass: Process skills in general and in 2 subclass: Measuring and predicting and critical thinking in general and in 1 subclass: interpretation, than the control group at the 0.05 level of significance. The high achievers shoed only higher basic science process skill in general and in 3 subclass: Using space-time relationship, classifying and predicting, more than the low achieves at the 0.05 level of significance. The statistical interactions of learning achievement with learning model on learning achievement and critical thinking were not found to be significant. Whereas, the interaction of these two variables on basic science process skills in general and in 3 subclass: Measuring, classifying and predicting were found to be significant at the 0.05 level. Concussion/Recommendations: The 5 E-Leaning cycle with met cognitive techniques could develop efficiently learning achievement, basic science process skills and critical thinking of the students. The teachers, therefore, should be encourage and supported to implement this approach in teaching and learning environmental education in all grade levels.
\end{abstract}

Key words: Learning, environmental, education, techniques, handbook, basic science

\section{INTRODUCTION}

Environmental Studies was included in curriculum both for Elementary Education and High School Level since the early 1978 and in Senior High School Curriculum since 1981. Most of the content on Environmental studies consisted of natural stories and phenomena as well as involved with activities performed by human beings since the industrial revolution on technology development and rapid growth of human population. They were increasing collected serious problems respectively. It was supported by the conference in "Human' s Ecology" in Stockholm, Sweden in June 1972 of United Nations Organization. The causes of serious demolished natural resources and increasing number of world population, were stated. According to the conference, Environmental education was an instrument in solving

Corresponding Author: Phramaha Charoen Buntod, Faculty of Environment and Resource Studies,

University of Mahasarakham, Maha Sarakham, 44000 Thailand Tel: +66-43-74-2135 
problems and improving quality of environment in the long run. Besides, it was an important aspect of strategies collaborated by various countries to fight with crisis of the global environmental problems (Greenall, 1980; Blank, 2002).

Therefore, the guidelines for instructional management were established to be relevant to the Science nature in which inquiry teaching or discovery learning for knowledge of Science Process Skill, had to be focused on so that people's intelligence and attitude toward Science could be developed (Raghubir, 1979; Hotstein and Luneta, 1982; UNESCO, 1976). In general, the nature of Science inquiry had to be based on former theories and assumptions as guidelines of study (Welch, 1981; Bybee et al., 1991). Since the students would be the persons who construct knowledge and meaning by themselves according to their prior knowledge and thought (Garnett and Treagust, 1992). Those teaching guidelines were relevant to Piaget (1994) Developmental Theory, teaching for meaningful learning (Ausubel, 1969; Posner et al., 1982) and Constructivism. So, in science learning, the students had to used their Prior Knowledge Conceptions as a guided instrument and cause of meaningful learning (Abimbola, 1988; Gedik et al., 2003). Moreover, it was based on guidelines of former thought and knowledge to interact with all collected experiences (Wheatley, 1991). The students had to construct the new knowledge by themselves (Hewson and Hewson, 1983). This teaching approach was congruent with learning theory of Constructivist with assumption that the students would be persons who selected and rank the received information as well as construct new meaning from the information based on prior knowledge.

According to research studies and related literature, found that the instructional activity management based on 5 phases of learning cycle using Metacognition, was appropriate for being applied to every level of students, developing each student' intellectual development in higher level. As a result, the students would discover or learn skill in thinking, considering and solving problems carefully and efficiently for long lasting learning. Therefore, it should be applied in instructional management of Environmental Studies which no one used to study apply in instructional management of Environmental Studies, by comparing to learning by teacher's manual, in order to study that whether the effect of the instructional activity management would develop basic science process skill and learning critical thinking in higher level. The future findings of this study would be useful for developing and improving the environmental studies instructional model to be more appropriate and efficient.

\section{MATERIALS AND METHODS}

Study area: For this research, Tripitaka School, Maha Wachiralongkorn King College, Wangnoi District, Pranakon Sri-Ayuthaya Province, under jurisdiction of The Office of National Buddhism Religion, from 3 classrooms.

Research method: This study was an experimental study. The samples were 75 monks. They were selected by cluster random sampling by lots, with following Phases and experimental methods: (1) preparation phase, (2) experimentation and data collection phase and (3) concluding phase.

\section{RESULTS}

Local wisdom type: The researcher presents the findings from experiment as in Table 1.

According to Table 1, found that there were significant differences between the students with different learning achievements and models at 0.05 level. But, there was no interaction between learning achievement and models on all 3 aspects of learning achievement.

According to Table 2, found that there were significant differences between students with different learning achievements and models, obtained their average posttest scores from each aspect of basic science process skill, at 0.05 level. There was a significant interaction between learning achievement and models on each aspect posttest of basic science process skill learning achievement, at 0.05 level.

According to Table 3, found that there was no significant difference in each aspect posttest between students with different critical thinking.

Table 1: A comparison of the overall learning achievement, basic science process skill and critical thinking, from posttest of students with different learning achievements and studying by different learning models (two-way MANCOVA)

\begin{tabular}{llllrc}
\hline Source of variance & No. of aspects & df for hypothesis (df1) & df for error (df2) & F & p \\
\hline Learning achievement & 3 & 3 & 69 & 9.675 & $0.000^{*}$ \\
Learning model & 3 & 69 & 1.340 & $0.000^{*}$ \\
Learn ach X learn model & 3 & 69 & 0.316 & 0.814 \\
\hline *: Significant at 0.05 level & & & &
\end{tabular}


Table 2: A comparison of each aspect of basic science process skill from the posttest of students with different Science learning achievements and studying by different learning models (two-way MANCOVA)

\begin{tabular}{lllll}
\hline & Multivariate test & & \\
& & & \\
Source of variance & No. of aspects & df for hypothesis (df1) & df for error (df2) & F \\
\hline Learning achievement & 8 & 8 & 64 & 7.490 \\
Learning model & 8 & 8 & 64 & 4.931 \\
Learn ach X learn model & 8 & 8 & 64 & $0.000^{*}$ \\
*. Significant at 0.05 level & & & & $0.000^{*}$ \\
\end{tabular}

*: Significant at 0.05 level

Table 3: A comparison of each aspect posttest critical thinking of students with different science learning achievement and learning by different learning models (two-way MANCOVA)

\begin{tabular}{|c|c|c|c|c|c|}
\hline \multirow[b]{2}{*}{ Source of variance } & \multirow[b]{2}{*}{ No. of aspect } & \multicolumn{4}{|l|}{ Multivariate test } \\
\hline & & df for hypothesis (df1) & df for error (df2) & $\mathrm{F}$ & $\mathrm{p}$ \\
\hline Learning achievement & 5 & 5 & 67 & 1.035 & $0.000^{*}$ \\
\hline Learning model & & 5 & 67 & 3.039 & $0.000^{*}$ \\
\hline Learn ach X learn model & & 5 & 67 & 0.264 & 0.931 \\
\hline
\end{tabular}

*: Significant at 0.05 level

There was no significant interaction between learning achievement and models. But, there were significant differences in each aspect posttest Critical Thinking between students with different learning models at 0.05 level.

\section{DISCUSSION}

There were no differences in overall and each aspect of learning achievement and critical thinking between students with high learning achievement and low learning achievement. But, they had the overall and each aspect of 3 aspects of basic science process skill, higher than those with low learning achievement at 0.05 significant level.

It might be because of:

- Although the high learning achievement students and low achievement students had different intellectual ability and prior knowledge, there were no differences in learning achievement and critical thinking between students with high learning achievement and students with low learning achievement. The findings reflected the rational that the appropriate or efficient instructional activity management, for instance, the instruction providing students' opportunity in Hands-on Activities by using Metacognitive Technique which as higher ordered thinking (Beeth, 1998) as well as cooperative learning among students working in small group, the students could help each other, especially the high achievement students supported the low achievement students (Slavin, 1995). As a result, the low achievers gained more benefit from learning. There were no differences between both group students
- The high achievement students had higher achievement motivation (Alderman and Cohen 1985), self efficacy (Gan et al., 2009) and attention than the low achievement students (Rimor et al., 2008). Therefore, they could better apply their intellectual process based on learning cycle focusing on science process skill than those with low achievement as well as develop their intellectual ability or science process skill

\section{CONCLUSION}

The low achievement students had the overall and each aspect of 3 aspects in posttest Basic Science Process Skill higher than those with low achievement at 0.05 significant level. There was no interaction between learning achievement and model on learning achievement and critical thinking. But, there was an interaction in the overall and each aspect of posttest of learning achievement and model on basic science process skill at 0.05 significant level.

\section{ACKNOWLEDGEMENT}

This thesis completely finished with the kindness and support by Associate Professor Dr. Paitoon Sooksri-ngam, Thesis Advisor, Associate Professor Dr. Chaiyod Reungsuwan, the chairman of thesis oral examination, Dr. Adisak Singseewo, Thesis Co-advisor and Dr. Netchanok Jansawang, outside expert for kindly providing the advice, suggestion and investigation the mistakes very well. Besides, thank you the administrators, teachers, students of Maha Wachiralongkorn King College for very good cooperation. 


\section{REFERENCES}

Abimbola, I.O., 1988. The problem of terminology in the study of student conceptions. Sci. Educ., 72: $175-184$.

Alderman, M.K. and M.W. Cohen, 1985. Motivation theory and practice for teachers. ERIC teacher education monograph No. 4.

http://www.eric.ed.gov/ERICWebPortal/custom/po rtlets/recordDetails/detailmini.jsp?_nfpb=true\&_\& ERICExtSearch_SearchValue_0=ED261060\&ERI CExtSearch_SearchType_0=no\&accno=ED261060

Ausubel, D.P., 1969. Some Psychological and Education Limitations of Learning by Discovery. In: Readings in Science Education for the Secondary School, Amdersem, H.O. (Ed.). Macmillan Company, New York, pp: 97-113.

Beeth, M.E., 1998. Teaching for conceptual change: Using status as a metacognitive tool. Sci. Educ., 82: 343-350.

Blank, L., 2002. Get wild about filmmaking. CLEARING: Environmental education resources for teachers, 111: 32-33.

Bybee, R.W., J.C. Powell, J.D. Ellis, J.R. Giese, L. Parisi and L. Singleton, 1991. Integrating the history and nature of science and technology in science and social studies curricula. Sci. Educ., 75: 143-155. DOI: $10.1002 /$ sce.3730750113

Gan, Z., R.K. Lodewyk and T. Zhang, 2009. The role of ability beliefs and incentives in middle school student' intention, cardiovascular fitness and effort. J. Teach. Phys. Educ., 28: 3-20.

Garnett, P.J. and D.F. Treagust, 1992. Conceptual difficulties experienced by senior high school students of electrochemistry: Electric circuits and oxidation-reduction equation. J. Res. Sci. Teach., 29: 121-142.

Gedik, E., O. Geban, H. Ertepınar and E. Ceylan, 2003. Facilitating conceptual change in electrochemistry using conceptual change approach. http://www1.phys.uu.nl/esera2003/programme/pdf/ 239S.pdf

Greenall, A., 1980. Environmental education in school policies and programme. The Curriculum Development Center, Canberra. http://www.ejmste.com/v5n3/EURASIA_v5n3_Ta sar.pdf

Hewson, P.W. and M.G. Hewson, 1983. Effect of instruction using student' prior knowledge and conceptual change strategies of science learning. J. Res. Sci. Teach., 20: 731-734. http://www.allacademic.com/meta/p_mla_apa_rese arch_citation/1/1/7/5/6/p117561_index.html
Hotstein, A. and V.N. Luneta, 1982. The role of laboratory in science teaching: Neglected aspects of research. Rev. Educ. Res., 55: 201-217. http://www.jstor.org/stable/1170311

Piaget, J., 1994. Cognitive development in children. J. Res. Sci. Teach., 10: 170-186.

Posner, G.J. K.A. Strike, P.W. Hewson and W.A. Gertzog, 1982. Accommodation of a scientific conception: Toward a theory of conceptual change. Sci. Educ., 66: 211-227.

Raghubir, K.P., 1979. The laboratory-investigative approach to science instruction. J. Res. Sci. Teach., 66: 13-17.

Rimor, R., R. Reingold and A. Kalay, 2008. The relationship between instructor's scaffolding and students' metacognition in online academic course, pp: 122-129. http://telempub.openu.ac.il/users/chais/2007/morning_2/M2_1 2.pdf

Slavin, M.J., 1995. The first federal summer theatre: Retraining for the New American theatre. Ph.D., Bowling Green State University, pp: 210. http://www.wpamurals.com/dissert.htm

UNESCO., 1976. The Belgrade charter. Connect, 1: 2. http://www.naaee.org/npeee/materials_guidelines/i ntro.html

Welch, W.W., 1981. Inquiry and the Science Teacher. In: What Research Says to the Science Teacher, Harms, N.C. and R.E. Yager (Eds.). National Science Teachers Association, Washington DC., pp: 53-64.

Wheatley, G.H., 1991. Constructivist perspectives on science and mathematics learning. Sci. Educ., 75: 9-21. 